\title{
Phylogeny, phylogeography, and evolution in the Mediterranean region: News from a freshwater mussel (Potomida, Unionida)
}

\author{
Elsa Froufe ${ }^{\mathrm{a}, *}$, Vincent Prié ${ }^{\mathrm{b}}$, João Faria ${ }^{\mathrm{c}}$, Mohamed Ghamizi ${ }^{\mathrm{d}}$, Duarte V. Gonçalves e,f,g, \\ Mustafa Emre Gürlek ${ }^{\mathrm{h}}$, Ioannis Karaouzas ${ }^{\mathrm{i}}$, Ümit Kebapçi ${ }^{\mathrm{j}}$, Hülya Şereflişan ${ }^{\mathrm{k}}$, Carina Sobral ${ }^{\mathrm{a}}$, \\ Ronaldo Sousa ${ }^{\mathrm{a}, \mathrm{l}}$, Amílcar Teixeira ${ }^{\mathrm{m}}$, Simone Varandas ${ }^{\mathrm{n}}$, Stamatis Zogaris ${ }^{\mathrm{i}}$, Manuel Lopes-Lima ${ }^{\mathrm{a}}$ \\ ${ }^{a}$ CIIMAR/CIMAR - Interdisciplinary Centre of Marine and Environmental Research, University of Porto, Rua dos Bragas 289, P 4050-123 Porto, Portugal \\ ${ }^{\mathrm{b}}$ Muséum National d'Histoire Naturelle, Département Systématique et Evolution, ISyEB (UMR 7205 CNRS/UPMC/MNHN/EPHE), 43, Rue Cuvier, 75231 Paris, France

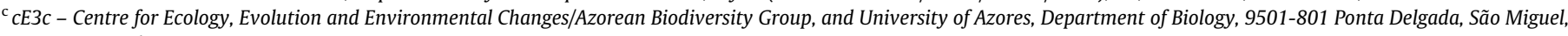 \\ Azores, Portugal \\ ${ }^{\mathrm{d}}$ Muséum d'Histoire Naturelle de Marrakech, Université Cadi Ayyad, Faculté des Sciences, Semlalia, B.P. 2390 Marrakech, Morocco \\ ${ }^{e}$ CIBIO/InBIO, Research Centre in Biodiversity and Genetic Resources, University of Porto, R. Padre Armando Quintas, 4485-661 Vairão, Portugal \\ ${ }^{\mathrm{f}}$ Department of Biology, Faculty of Sciences, University of Porto, Rua do Campo Alegre, 4169-007 Porto, Portugal \\ ${ }^{\mathrm{g}}$ Institute of Evolutionary Biology (CSIC-Universitat Pompeu Fabra), Passeig Marítim de la Barceloneta 37-49, E-08003 Barcelona, Spain \\ ${ }^{\mathrm{h}}$ Süleyman Demirel University, Water Institute, Isparta, Turkey \\ ${ }^{\mathrm{i}}$ Institute of Marine Biological Resources and Inland Waters, Hellenic Centre for Marine Research (HCMR), 46.7 km Athens-Sounio Av., Anavissos 19013, Greece \\ ${ }^{\mathrm{j} B i o l o g y}$ Department of Art and Science Faculty, Mehmet Akif Ersoy University, Burdur, Turkey \\ ${ }^{\mathrm{k}}$ Faculty of Marine Sciences and Technology, Iskenderun Technical University, 31200 Iskenderun, Hatay, Turkey \\ ${ }^{1}$ CBMA - Centre of Molecular and Environmental Biology, Department of Biology, University of Minho, Campus Gualtar, 4710-057 Braga, Portugal \\ ${ }^{m}$ CIMO-ESA-IPB - Mountain Research Centre, School of Agriculture, Polytechnic Institute of Bragança, Campus de Santa Apolónia, Apartado 1172, 5301-854 Bragança, Portugal

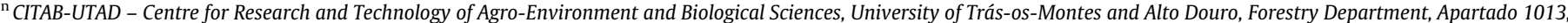 \\ 5001-811 Vila Real, Portugal
}

\section{A R T I C L E I N F O}

\section{Article history:}

Received 21 January 2016

Revised 19 April 2016

Accepted 23 April 2016

Available online 24 April 2016

\section{Keywords:}

Refugia

Conservation

Diversity

Freshwater mollusks

Unionida

\begin{abstract}
A B S T R A C T
The Potomida genus (Bivalvia, Unionida) has a Circum-Mediterranean distribution and like other freshwater mussel species, its populations have suffered dramatic declines. Although this genus is currently considered as monotypic, it has a long history of taxonomic revisions and presently many aspects of its systematics and evolutionary history are unclear. We sampled a total of 323 individuals from 39 different sites across the Potomida genus distribution, and sequenced two mitochondrial (16S rDNA and Cytochrome c Oxidase Subunit I) and one nuclear (28S rDNA) genes to clarify its phylogeny and phylogeographic history. Our results show that the genus includes two well-supported clades, one comprising solely the western Mediterranean species Potomida littoralis, and the other including two eastern Mediterranean species, the Greek endemic P. acarnanica and the Anatolian and Middle Eastern P. semirugata. We suggest that Potomida started radiating during the upper Miocene, and that both vicariance and dispersal events shaped the diversification and distribution of the genus along the Mediterranean region. $P$. littoralis is further divided in two mitochondrial lineages, one restricted to Europe and the other occurring mostly in North Africa. Moreover, some European basins present both lineages in sympatry. The conservation status of the three recognized species should be reevaluated, particularly $P$. acarnanica, since it is restricted to two Greek river basins presenting a high risk of extinction. Overall, our results clarify some important gaps in knowledge concerning the phylogeny, phylogeography and evolution of the Potomida genus in the Mediterranean region with important taxonomical, ecological and conservational implications.
\end{abstract}

(c) 2016 Elsevier Inc. All rights reserved.
* Corresponding author at: CIIMAR/CIMAR - Interdisciplinary Centre of Marine and Environmental Research, University of Porto, Rua dos Bragas 289, P 4050-123 Porto, Portugal.

E-mail address: elsafroufe@gmail.com (E. Froufe).

\section{Introduction}

The Mediterranean region has long been recognized for its exceptional species richness and high level of endemism, being classified as a hotspot of biodiversity (Myers et al., 2000). This 
region is one of the most complex, diverse, and heterogeneous areas of the planet and includes a unique combination of geographic, climatic and human histories that resulted in a remarkable evolutionary radiation of plants and animals colonizing a myriad of aquatic and terrestrial ecosystems (Blondel et al., 2010). The Mediterranean region is particularly rich in endemic plant species (Médail and Diadema, 2009) but a high proportion of animal species are also unique including $66 \%$ of amphibians, $50 \%$ of crabs and crayfish, $48 \%$ of reptiles, $25 \%$ of mammals and $14 \%$ of dragonflies, among others (Cuttelod et al., 2008). This high biodiversity is mainly found in two distinct areas, one in the West (especially in the Iberian Peninsula and Northwest Africa) and the other in the East (especially in the Balkans and Anatolia) (Schmitt, 2007). These areas are also considered temperate refugia where populations of plants and animals were often isolated during unfavorable climatic periods, resulting in strong genetic imprints (e.g. Hewitt, 1999; Taberlet et al., 1998). The existence of fragmented distributions within Mediterranean refugia, together with the dispersion processes and gene flow occurring during range expansions in the interglacial periods, has resulted in complex patterns of population genetic structure (e.g. Feliner, 2011; Schmitt, 2007).

The complex geography of the Mediterranean region, including land discontinuities and topography, has produced a multitude of different sub-centers responsible for present-day complex genetic differentiation patterns and uneven distributions of regional diversities. For example, the Strait of Gibraltar contributed to the diversification of Iberian and North African terrestrial and freshwater organisms, with several biogeographical studies describing different clades on both sides (e.g. Paulo et al., 2008 and references herein). The Messinian Salinity Crisis (MSC) occurred around 5.6 million years ago (Mya), at the end of the Miocene, causing the separation of the Mediterranean Sea from the Atlantic Ocean and temporarily desiccating the Mediterranean in a series of events (for a review see Rouchy and Caruso, 2006). This allowed interchange between the present mainland discontinuities followed by the re-establishment of the marine connection at 5.3 Mya (Krijgsman et al., 1999) fragmenting the ranges of the taxa involved.

Numerous studies have shown distinct patterns ranging from strong genetic splits (e.g. Fonseca et al., 2009; García-París et al., 2003; Miraldo et al., 2011; Steinfartz et al., 2000) to low mitochondrial differentiation across both sides of the Strait of Gibraltar (e.g. Carranza et al., 2006; Fromhage et al., 2004; Schmitt et al., 2006). The Eastern Mediterranean region, located at the margin of the Eurasian and African plates, has another complex geological history with multiple events of land divisions and connections during the late Tertiary (Bianco, 1990; Blondel et al., 2010; Schmitt, 2007). These also resulted in distinct phylogeographic patterns, from endemicity (e.g. Bohlen et al., 2006; Sotiropoulos et al., 2007), to widespread lineages of variable genetic variation (e.g. Veith et al., 2003; Stöck et al., 2012).

In this context, and given the heightened scientific interest in glacial refugia and postglacial colonization routes in the Mediterranean region, it is unexpected that the diversity and phylogeographic patterns of freshwater mussels (Bivalvia, Unionida) remain poorly understood. Aquatic freshwater species, such as freshwater mussels, are excellent candidates to study the extent of lineage diversification in this region due to their low dispersal ability. However, little attention has been given to their genetic diversity, especially when compared with other faunal groups or even with freshwater mussels from other continents (e.g. North America; Elderkin et al., 2008; Mock et al., 2013; Zanatta and Harris, 2013). In fact, published studies on these taxa evaluated genetic diversity based mainly of partial distributions (e.g. Anodonta sp. Geist et al., 2010; Nagel et al., 1996; and Lopes-Lima et al., 2016a; Margaritifera margaritifera (Linnaeus, 1758),
Machordom et al., 2003; and Unio sp. Araujo et al., 2005, 2009; Prié and Puillandre, 2014). Detailed phylogeographic data covering entire species ranges is still insufficient (but see Froufe et al., 2014; Froufe et al., 2016a, for two rare examples).

Potomida Swainson, 1840 is a freshwater mussel genus with a Circum-Mediterranean distribution (Lopes-Lima et al., 2014). Although this genus is currently considered monotypic, it has a long history of taxonomic revisions, and presently its taxonomic status, and many aspects of its evolutionary history, remain unclear. The traditional conchological characters, of limited use for identifying taxonomic units due to the high phenotypic plasticity of unionoid mussels, are responsible for more than 90 synonyms described for $P$. littoralis (Cuvier, 1798) before the middle of the twentieth century (Graf, 2010). Haas (1969) has recognized this caveat, synonymizing many of these synonyms, and integrating all into eight $P$. littoralis subspecies (Fig. 1). These taxa were never validated with molecular studies, and some subspecies have been recently re-evaluated. The Iberian P. l. umbonata (Rossmässler, 1844), was synonymized with $P$. l. littoralis (Araujo et al., 2009). Khalloufi et al. (2011) have shown that P. l. fellmanni (Deshayes, 1848) populations present in Tunisia have considerable genetic differentiation of $3.16 \%$ (COI) from the Iberian P. l. littoralis populations. However, the remaining distribution of the subspecies, i.e., Morocco and Algeria, was not included in the study. Therefore, to confirm the validity of $P$. l. fellmanni these data need to be included. Finally, based on a comprehensive comparative morphological and anatomical study, P. l. homsensis (Lea, 1865) was properly re-assigned to other family (Margaritiferidae) and is now Margaritifera homsensis (Lea, 1865) (Smith, 2001). As for the remaining four subspecies, no recent data is available, and so the taxonomic status of all these subspecies is still unclear. This is worrisome since Potomida populations (Barea-Azcón et al., 2008; Pérez-Quintero, 2007; Sousa et al., 2008) and other freshwater mussels (e.g. Lopes-Lima et al., 2016b; Prié et al., 2014; Sousa et al., 2015, 2016), have suffered dramatic declines. For this reason, $P$. littoralis has been recently listed as Endangered in the IUCN Red List (Lopes-Lima et al., 2014).

Given the above uncertainties, in tandem with the conservation status of the Potomida genus, there is an urgent need for a comprehensive phylogeographic study to unravel its evolutionary history and taxonomy. In this study we used information from two mitochondrial (16S rDNA and Cytochrome c Oxidase Subunit I) and one nuclear (28S rDNA) genes from 323 individuals in 39 sites sampled across the Potomida distribution. Sequences for these three genes were combined and analyzed to: (i) clarify and establish the phylogeny and taxonomy of the genus; (ii) propose historical biogeographic and demographic scenarios to accommodate the genetic variation observed; and (iii) discuss the conservation implications of the obtained results. We also aim to test the role of the MSC as a vicariant event as well as the "oriental origin" hypothesis in the Balkans, using a calibrated phylogeny.

\section{Materials and methods}

\subsection{Sample collection}

Potomida specimens were collected from 39 sites across its reported distribution, in Morocco, Iberia, France, Greece and Turkey (Fig. 2 and Table S1). A small sample from the foot was collected in the field (following Naimo et al., 1998) and placed in $99 \%$ ethanol, returning the mussel to the substrate immediately afterwards. Genomic DNA was extracted from the tissue samples, using a standard high-salt protocol (Sambrook et al., 1989). Voucher specimens from France are deposited in Muséum National d'Histoire Naturelle (Paris, France) and voucher specimens from 


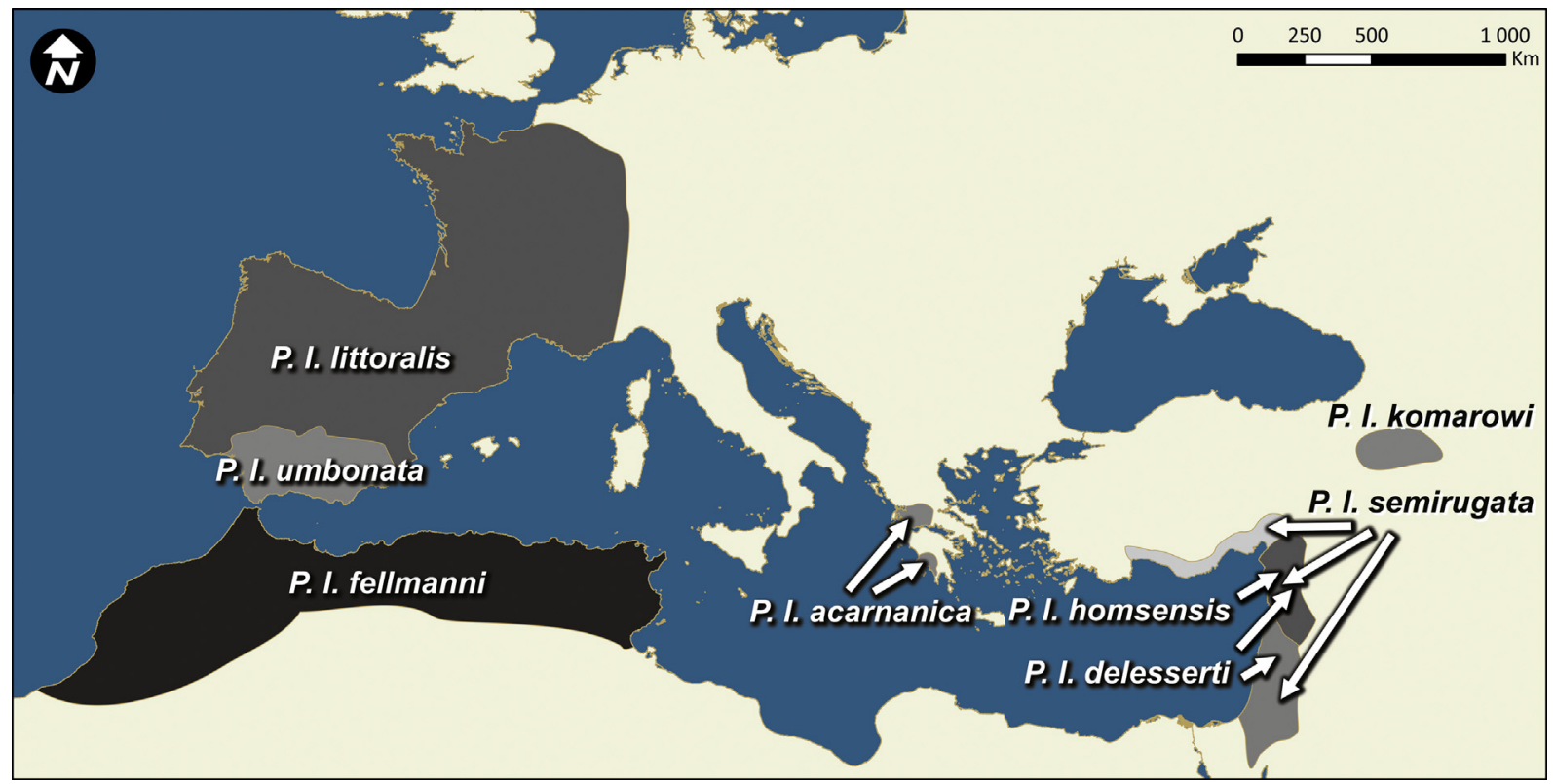

Fig. 1. Distribution map of the eight Potomida littoralis subspecies recognized by Haas (1969).

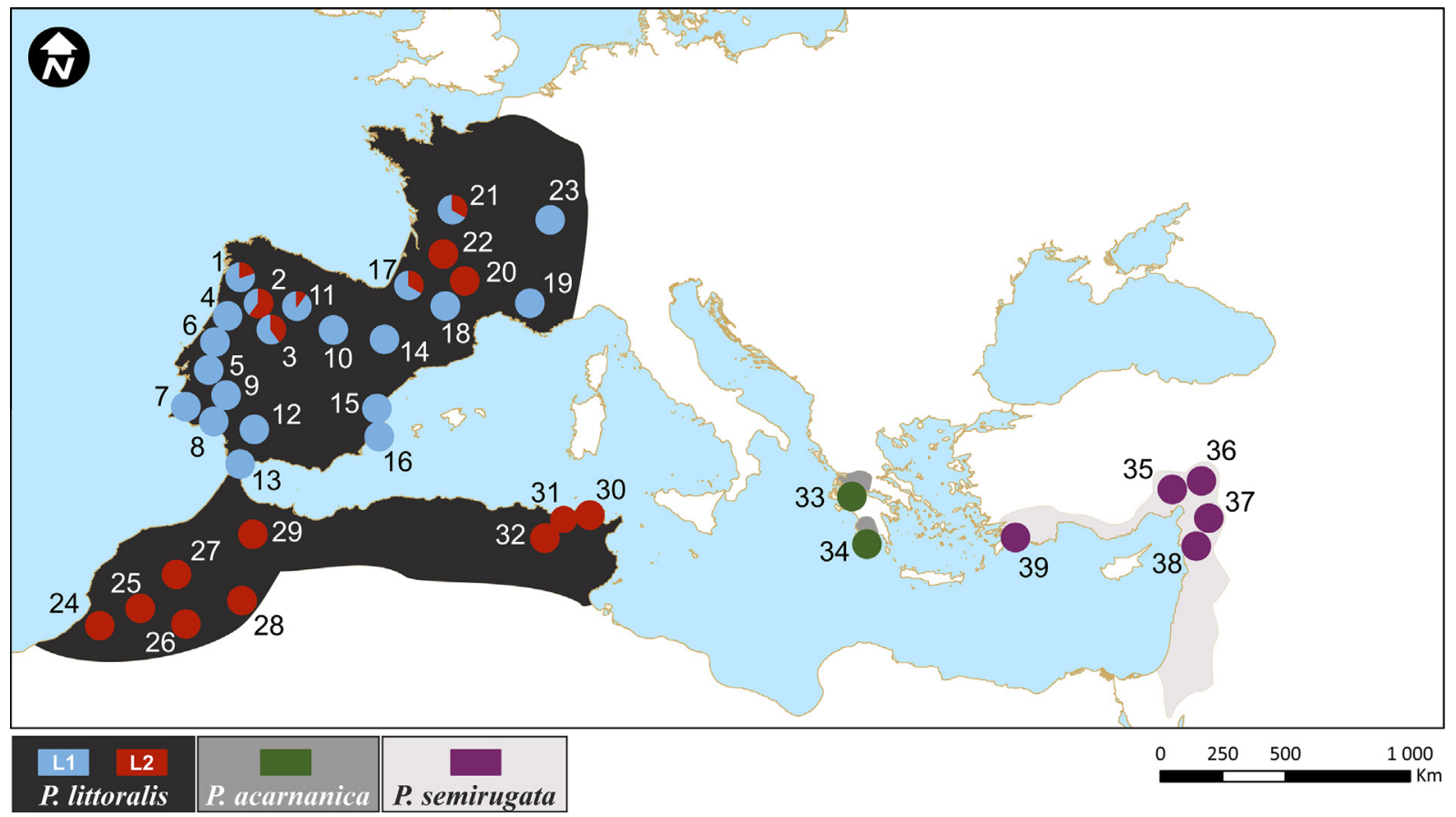

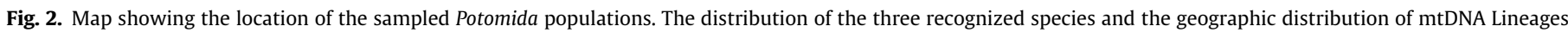
are represented in pie charts.

Morocco, Iberia, Greece and Turkey have been deposited in Museu Nacional de História Natural e da Ciência (Lisboa, Portugal).

\subsection{Sequencing, alignment, phylogenetic analyses}

A total of 323 Potomida specimens and four outgroup species: Pronodularia japanensis (Lea, 1859), Lamprotula leai (Griffith \& Pidgeon, 1833), Leguminaia wheatleyi (Lea, 1862) and Microcondylaea bonellii (A. Ferussac 1827), were amplified for mtDNA 16Sr DNA (16S rRNA; ca. 500 bp fragment), with $16 \mathrm{SL}$ and $16 \mathrm{SH}$ primers
(Palumbi et al., 1991); the F-type mtDNA cytochrome oxidase subunit 1 gene (COI; ca. $700 \mathrm{bp}$ fragment), with LCO_22me and HCO_700dy primers (Walker et al., 2006, 2007); and for the nuclear 28Sr DNA (ca. $800 \mathrm{bp}$ fragment) with 28S-RD1.3f and 28S-rD4b primers (Whiting, 2002). PCR conditions are described in Froufe et al. (2014) with annealing temperatures ranging from $49{ }^{\circ} \mathrm{C}(16 \mathrm{~S})$ to $55^{\circ} \mathrm{C}$ (COI and 28S). Sequences were obtained using the BigDye sequencing protocol (Applied Biosystems 3730xl) by Macrogen Inc., Korea. Forward and reverse sequences were edited and assembled using ChromasPro 1.7.4 (Technelysium, Tewantin, Australia). 
Alignments were built with ClustalW, in Bioedit 7.2.5 (Hall, 1999), including sequences from GenBank (France, Tunisia and Turkey; Table S1). Unionida exhibit a peculiar mode of mitochondrial DNA transmission, known as doubly uniparental inheritance (DUI), of mitochondrial DNA (Zouros et al., 1994a,b; Hoeh et al., 1996). As a result, the nucleotide divergence between female and male mitochondrial genomes of $P$. littoralis is at least 30\% (Froufe et al., 2016b). In the present study, this value was used as a reference to assure that the obtained $\mathrm{COI}$ sequences were indeed all F-type.

Topological differences among single-marker phylogenies were assessed according to Mason-Gamer and Kellogg (1996) and a final concatenated alignment, including outgroups, was then analyzed using Maximum Likelihood (ML) and Bayesian Inference (BI) methods. The best-fit model of nucleotide substitution under corrected Akaike Information Criterion was selected using JModelTest 2.1.7 (Darriba et al., 2012) for each gene partition. ML trees were built in PhyML (Guindon and Gascuel, 2003) with 1000 bootstrap replicates. Phylogenetic BI was performed on MrBayes version 3.2.6 (Ronquist et al., 2012) with sequences also partitioned according to genes. Analyses started with program generated trees, with four heated Markov chains with default incremental heating; two independent runs $24 \times 10^{6}$ generations long were sampled at intervals of 1000 generations producing a total of 24,000 trees. Burnin was determined upon convergence of log likelihood and parameter estimation values using Tracer 1.6 (Rambaut et al., 2014). Haplotypes, for each gene, were retrieved using DNASp v5.1.0.1 (Rozas and Rozas, 1995). All new sequences have been deposited in GenBank (Table S1).

\subsection{Divergence time estimates}

At present, no internally calibrated molecular clock is available for $P$. littoralis (using the fossil record). Therefore, divergence times among lineages were estimated from COI sequences using Beast v1.8.2 (Drummond and Rambaut, 2007), and the substitution rate of $0.265 \pm 0.06 \%$ per million years recently estimated for Unio (Froufe et al., 2016a) was applied with normal distribution prior. Individual haplotypes were used to reduce computational load and optimize the analysis. The dataset was run under a TIM3 substitution model according to jModelTest results. An uncorrelated lognormal relaxed clock (Drummond et al., 2006) was used, and the tree prior was set to yule speciation process (Gernhard, 2008; Yule, 1925) given the nodes of interest are at an interspecific level. Other parameters used default settings. The random seed was 1434916511075. The analysis ran for $10^{7}$ generations, sampling every 1000 generations. The quality of the runs was assessed through parameter convergence using Tracer 1.6 (Rambaut et al., 2014). The maximum credibility tree of mean heights was constructed using TreeAnnotator and discarding 200 trees as burn-in.

\subsection{Diversity, differentiation and demographic analyses}

For each gene, sequences were joined in unrooted networks using the fixed connection limit of 30 steps criterion implemented in TCS 1.21 (Clement et al., 2000). Genetic distances ( $p$-uncorrected) within and between lineages were calculated with MEGA 6.0 (Tamura et al., 2013) and the diversity for each gene fragment (i.e. the number of haplotypes $(h)$, haplotype diversity (Hd) (Nei and Tajima, 1981) and nucleotide diversity $(\pi)$ (Nei, 1987) were calculated using the software DnaSP v5.1.0.1. An analysis of molecular variance (AMOVA) was performed using ARLEQUIN v.3.5.1.3 (Excoffier and Lischer, 2010) to estimate the hierarchical distribution of mtDNA genetic differentiation (COI), within and among populations, using DST (from the absolute number of nucleotide differences) and with 10,000 permutations.

In order to test for molecular signatures of demographic expansion of each of the major clades obtained in the phylogeny and hypothesizing post-Pleistocene range expansions, a pairwise mismatch-distribution analysis was carried out (Rogers and Harpending, 1992) and Fu's Fs (Fu, 1997), Tajima's D (Tajima, 1989) and Ramos-Onsins and Rozas' R2 (Ramos-Onsins and Rozas, 2002) statistics were calculated.

\section{Results}

\subsection{Phylogenetic relationships}

All mtDNA COI sequences obtained were considered F-type, since no sequences similar to the M-type were detected. There was no major length variation within each gene (lack of indels in the COI alignment and both $16 \mathrm{~S}$ and $28 \mathrm{~S}$ presenting four $1 \mathrm{bp}-$ gaps each) and no stop codons were observed after translating all sequences to amino acids. Following the methodology of MasonGamer and Kellogg (1996) there was no significant topological differences between estimates of phylogenies based on the individual gene trees. Thus, the three fragments were concatenated and analyzed in a combined approach. Model TIM3 was chosen for COI, $\mathrm{HKY}+\mathrm{G}$ for $16 \mathrm{~S}$ and GTG $+\mathrm{G}$ for $28 \mathrm{~S}$. The final combined data set included 1790 aligned positions for 323 individuals, comprising $608 \mathrm{bp}$ of COI, $491 \mathrm{bp}$ of $16 \mathrm{~S}$, and $691 \mathrm{bp}$ of $28 \mathrm{~S}$.

The concatenated tree topologies resulting from the single tree recovered from the ML and BI approaches were congruent and produced topologically identical trees. The results of the Bayesian phylogenetic analysis are shown in Fig. 3. The results show a well-resolved phylogeny that includes two well-supported sister clades: one comprising solely the Western Mediterranean species P. littoralis (Cuvier, 1798), and the other including two Eastern Mediterranean species, the Greek endemic P. acarnanica (Kobelt, 1879 ) and the relatively widespread Anatolian and Middle East $P$. semirugata (Lamarck, 1819). P. littoralis is divided in two major highly supported lineages (L1 and L2 in the phylogeny). L1 (blue ${ }^{1}$ ) is very shallow and includes the majority of the individuals collected in Iberian and French basins (Figs. 2 and 3). L2 (red) includes all the individuals collected in Morocco, the ones retrieved from GenBank from Tunisia and some individuals from North-West Iberia and French Atlantic basins, collected in sympatry with the individuals depicted in L1 (Table S1; Figs. 2 and 3). P. acarnanica individuals (from Greece) cluster together and join with high support with $P$. semirugata individuals collected in Turkey.

Measures of genetic diversity for the mitochondrial COI gene are summarized in Table 1 . Mean genetic distance ( $p$-uncorrected) ranged from $3.0 \%$ between $P$. acarnanica and $P$. semirugata and $4.2 \%$ between $P$. littoralis and $P$. semirugata (Table 1 ). Levels of haplotype diversity were higher in P. semirugata when compared to the remaining species (Table 1$)$. The divergence between the two P. littoralis lineages (i.e. L1 and L2 in the phylogeny, Fig. 3) was 2.4\%, with L2 showing higher levels of genetic variation (Table 1 ).

\subsection{Divergence time}

All ESS values assessed in Tracer v1.6 were above 200. The average estimated crown ages for the four lineages was between 1.38 and 2.88 Mya (Fig. 4), with the MCS far predating any of the $95 \%$ confidence intervals. Moreover, this analysis determined the age

\footnotetext{
${ }^{1}$ For interpretation of color in Fig. 3, the reader is referred to the web version of this article.
} 


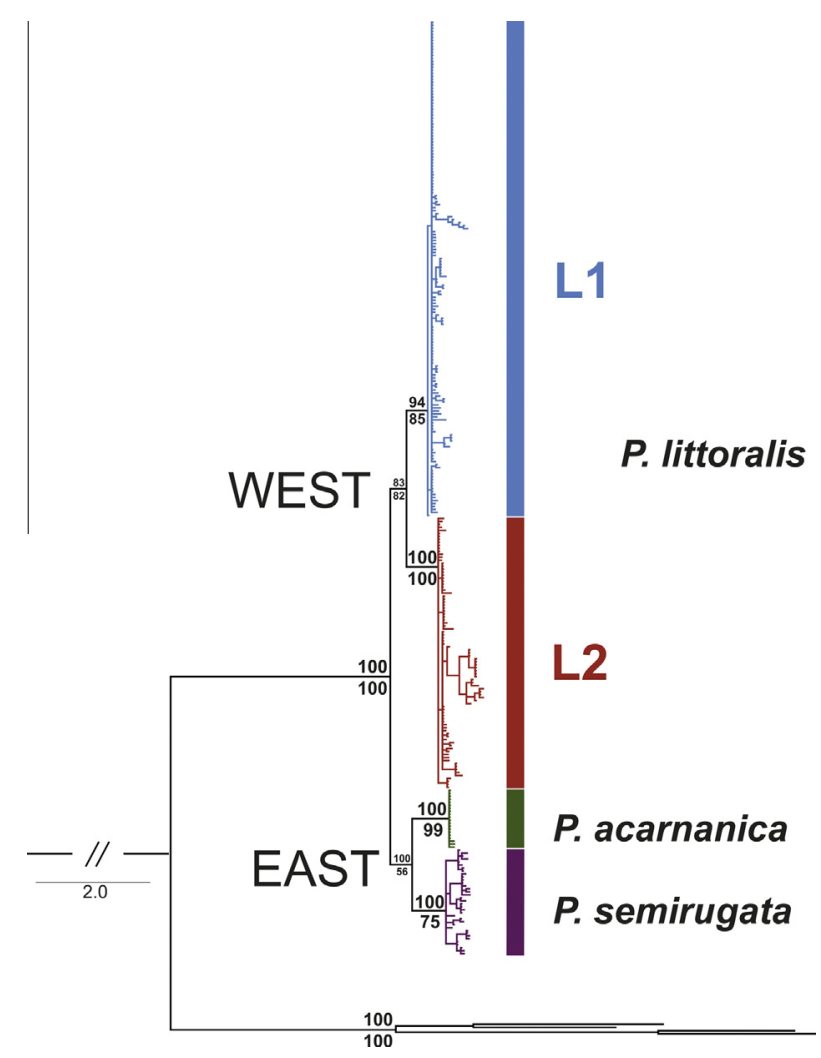

Fig. 3. Phylogenetic tree obtained by Bayesian Inference analysis of Potomida individuals $(\mathrm{COI}+16 \mathrm{~S}+28 \mathrm{~S})$. For the major nodes support values (\%) are given as Bayesian posterior probability above nodes and Bootstrap support (ML) below nodes.

of the most recent common ancestor (MRCA) of the Potomida genus as 8.1 Mya (Fig. 4).

\subsection{Genetic diversity, differentiation and historical demography}

Overall diversity estimates for each population and for each fragment are shown in Table 2. Haplotype networks based on mtDNA and nuclear sequences are presented in Fig. 5. As expected, very similar networks were retrieved for both mitochondrial genes, clearly identifying the same four lineages as the phylogenetic tree. $P$. littoralis L1 (blue) exhibits a star-like topology, with one high frequency central haplotype and several additional haplotypes connected by few-step mutations. In this haplogroup, the most common haplotype represents $50.8 \%$ (COI) and $62.2 \%(16 \mathrm{~S})$ of the individuals sampled from all localities in Iberia and France (Figs. 2 and 5, and Table S1). The haplogroup corresponding to P. littoralis L2 (red) in the phylogeny is linked by 10 steps to L1 (blue) and has several frequent haplotypes that are widely distributed. Most of these haplotypes were found in Morocco. However, 31 European individuals (marked with $*$ in the both mtDNA networks) cluster together with others from North Africa (Fig. 5). The Tunisian individuals retrieved from GenBank have 5 COI haplotypes (90-94) that cluster together at 5 mutations from the closest Morocco haplotype. P. acarnanica (green) is the species with the fewest haplotypes found (4 in COI and 2 in 16S; Fig. 5). On the other hand, from the $46 P$. semirugata individuals, 27 haplotypes were retrieved (purple, Fig. 5) being 21 only found in a single individual (COI; Table 2). The $28 \mathrm{~S}$ nuclear network was generally compatible with mtDNA in the diagnosis of the shared haplotypes between Europe and North Africa. P. acarnanica is represented by a single haplotype (green) and $P$. semirugata presents four unique haplotypes (purple; Fig. 5).

The results from AMOVA showed that differences between the two major Clades retrieved in the phylogeny, i.e., western and eastern Mediterranean (Fig. 3), accounted for $63.4 \%$ of overall variation in Potomida, whereas only $6 \%$ of total mitochondrial haplotype variation occurred within populations, with all structured levels presenting highly significant genetic differences (data not shown).

Tests of demographic history yielded significantly negative results for D (Tajima's) and Fs (Fu's) statistics for both $P$. littoralis and $P$. acarnanica (COI, Table 1 ) suggesting genuine rapid demographic expansion for these species. However, as $P$. littoralis is further divided in two additional lineages, the results of these tests were also carried on for each of these lineages. Only P. littoralis L1 yielded significantly negative results for the neutrality test (Table 1). Mismatch distributions showed similar patterns, supporting scenarios of demographic expansion in both $P$. littoralis L1 and P. acarnanica (Fig. 6), while for P. littoralis L2 and P. semirugata it revealed multimodal distributions (Fig. 6).

\section{Discussion}

\subsection{Phylogeny and systematics of the genus Potomida}

Results revealed a well-resolved phylogeny divided in two major allopatric clades, western and eastern Mediterranean. Reciprocal monophyly in mtDNA and diagnostic exclusivity of nuclear markers, in addition to allopatric distributions, allowed us to distinguish three species within the Potomida genus: $P$. littoralis (Cuvier, 1798) in the western clade and P. acarnanica (Kobelt, 1879) and P. semirugata (Lamarck, 1819) clustering in the eastern clade. The subspecies P. l. fellmani (Deshayes, 1848) and P. $l$. umbonata (Rossmässler, 1844) are here synonymized with $P$. $l$. littoralis (Cuvier, 1798) (L1 and L2). As for P. l. acarnanica (Kobelt, 1879 ) it is here recognized as $P$. acarnanica (Kobelt, 1879). The name $P$. acarnanica is valid for being the oldest description from the known distribution (i.e. Greece). Finally, both Middle East and Turkey subspecies are here synonymized and considered as P. semirugata (Lamarck, 1819). Among the various names that could apply to this Potomida species, e.g. P. delesserti (Bourguignat,

Table 1

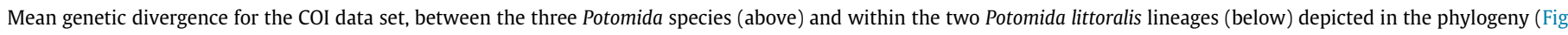

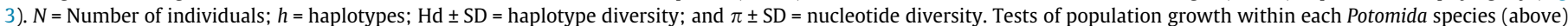

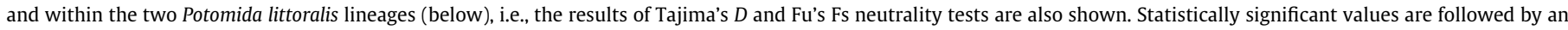
asterisk $(p<0.05)$.

\begin{tabular}{|c|c|c|c|c|c|c|c|c|c|}
\hline & P. littoralis & P. acarnanica & P. semirugata & $N$ & $h$ & $\mathrm{Hd}$ & $\pi$ & Fu's FS & $D$ \\
\hline P. littoralis & & & & 257 & 54 & $0.745 \pm 0.029$ & $0.01242 \pm 0.00062$ & $-2.504^{*}$ & -0.998 \\
\hline P. acarnanica & 0.037 & & & 20 & 4 & $0.284 \pm 0.128$ & $0.00082 \pm 0.00041$ & $-24.184^{*}$ & $-1.975^{*}$ \\
\hline P. semirugata & 0.042 & 0.030 & & 46 & 24 & $0.908 \pm 0.035$ & $0.00749 \pm 0.00069$ & -12.935 & -1.166 \\
\hline \multirow[t]{3}{*}{ P. littoralis } & & Lineage 1 & Lineage 2 & & & & & & \\
\hline & Lineage 1 & & & 166 & 29 & $0.423 \pm 0.050$ & $0.00139 \pm 0.00024$ & $-41.832^{*}$ & $-2.52401^{*}$ \\
\hline & Lineage 2 & 0.024 & & 91 & 25 & $0.894 \pm 0.017$ & $0.00752 \pm 0.00062$ & -6.794 & -0.91894 \\
\hline
\end{tabular}




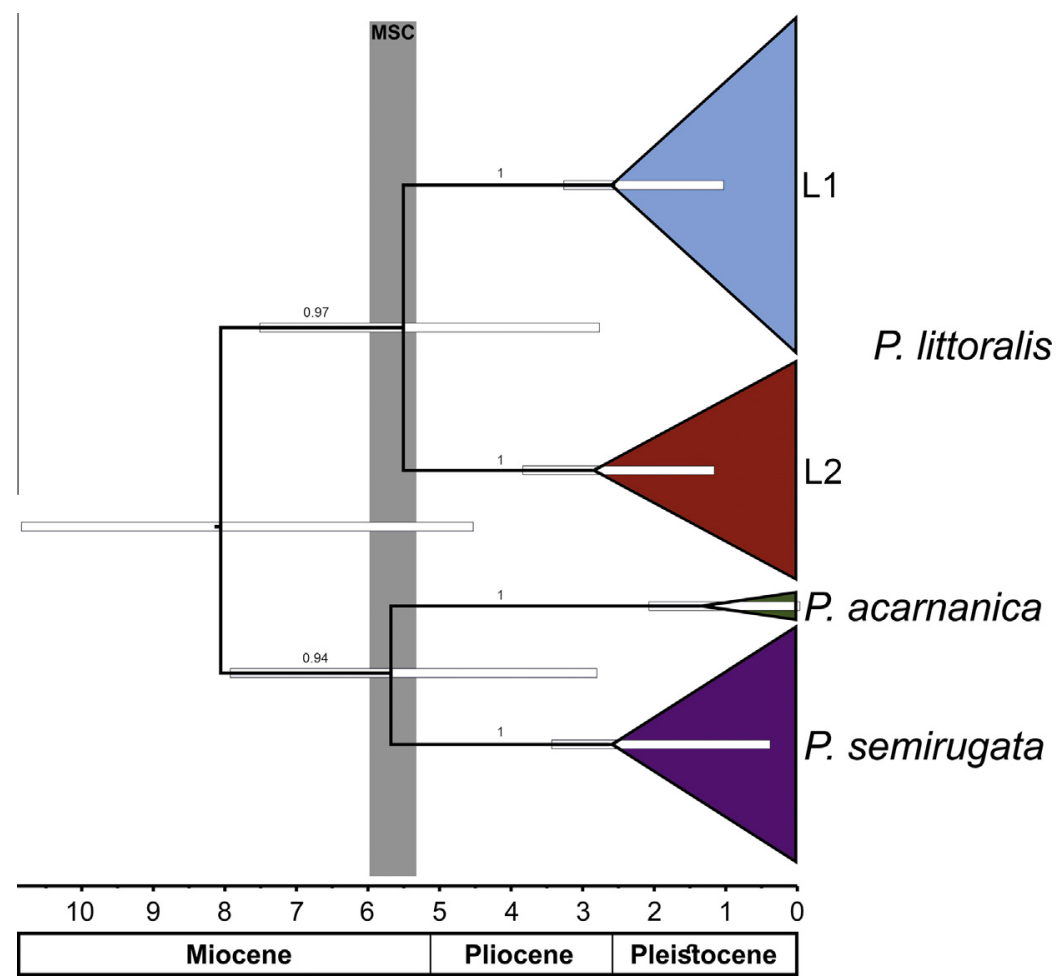

Fig. 4. BEAST maximum clade credibility tree for Potomida. Time scale is in million years. The grey horizontal bars indicate the height $95 \%$ HPD interval for the crown-age estimates. The size of the triangles is proportional to the number of haplotypes.

Table 2

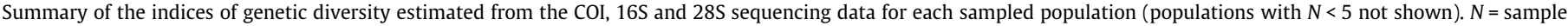
size; $h$ = number of haplotypes; Hd = haplotype diversity; $\pi$ = nucleotide diversity. Population numbers follow Fig. 2 and Table S1.

\begin{tabular}{|c|c|c|c|c|c|c|c|c|c|c|c|c|c|}
\hline \multirow[t]{2}{*}{ Population } & \multirow[t]{2}{*}{ Species } & \multicolumn{4}{|c|}{$\mathrm{COI}$} & \multicolumn{4}{|c|}{$16 \mathrm{~S}$} & \multicolumn{4}{|l|}{$28 \mathrm{~S}$} \\
\hline & & $N$ & $h$ & Hd & $\pi$ & $N$ & $h$ & Hd & $\pi$ & $N$ & $h$ & $\mathrm{Hd}$ & $\pi$ \\
\hline P1 & P. littoralis & 10 & 4 & 0.644 & 0.00826 & 10 & 4 & 0.644 & 0.00709 & 10 & 2 & 0.200 & 0.00029 \\
\hline P2 & P. littoralis & 10 & 5 & 0.822 & 0.01268 & 10 & 6 & 0.844 & 0.01276 & 10 & 3 & 0.511 & 0.00110 \\
\hline P3 & P. littoralis & 10 & 5 & 0.844 & 0.01096 & 10 & 2 & 0.533 & 0.00878 & 10 & 2 & 0.200 & 0.00029 \\
\hline $\mathrm{P} 4$ & P. littoralis & 10 & 5 & 0.844 & 0.00610 & 10 & 2 & 0.200 & 0.00041 & 10 & 2 & 0.200 & 0.00029 \\
\hline P5 & P. littoralis & 10 & 3 & 0.378 & 0.00066 & 10 & 2 & 0.200 & 0.00082 & 10 & 2 & 0.200 & 0.00029 \\
\hline P6 & P. littoralis & 10 & 3 & 0.511 & 0.00150 & 10 & 4 & 0.644 & 0.00155 & 10 & 3 & 0.644 & 0.00107 \\
\hline P7 & P. littoralis & 10 & 3 & 0.6 & 0.00110 & 10 & 2 & 0.200 & 0.00041 & 10 & 3 & 0.644 & 0.00268 \\
\hline P8 & P. littoralis & 10 & 5 & 0.667 & 0.00132 & 10 & 1 & - & - & 10 & 3 & 0.378 & 0.00058 \\
\hline P9 & P. littoralis & 10 & 7 & 0.911 & 0.00256 & 10 & 4 & 0.711 & 0.00197 & 10 & 2 & 0.200 & 0.00029 \\
\hline P10 & P. littoralis & 9 & 5 & 0.806 & 0.00411 & 9 & 1 & - & - & 9 & 2 & 0.222 & 0.00032 \\
\hline P11 & P. littoralis & 10 & 5 & 0.667 & 0.00519 & 10 & 4 & 0.533 & 0.00412 & 10 & 1 & - & - \\
\hline P12 & P. littoralis & 10 & 4 & 0.644 & 0.00150 & 10 & 2 & 0.200 & 0.00041 & 10 & 2 & 0.356 & 0.00052 \\
\hline P13 & P. littoralis & 10 & 5 & 0.756 & 0.00216 & 10 & 2 & 0.200 & 0.0041 & 10 & 3 & 0.511 & 0.00110 \\
\hline P14 & P. littoralis & 10 & 1 & - & - & 10 & 1 & - & - & 10 & 3 & 0.600 & 0.00165 \\
\hline P15 & P. littoralis & 10 & 3 & 0.378 & 0.00267 & 10 & 3 & 0.378 & 0.00114 & 10 & 2 & 0.200 & 0.00058 \\
\hline P16 & P. littoralis & 10 & 1 & - & - & 10 & 1 & - & - & 10 & 3 & 0.644 & 0.00191 \\
\hline P17 & P. littoralis & 9 & 4 & 0.806 & 0.01106 & 9 & 3 & 0.750 & 0.00926 & 9 & 2 & 0.389 & 0.00057 \\
\hline $\mathrm{P} 21$ & P. littoralis & 12 & 6 & 0.758 & 0.01268 & 12 & 2 & 0.485 & 0.00798 & 10 & 1 & - & - \\
\hline $\mathrm{P} 22$ & P. littoralis & 10 & 3 & 0.378 & 0.00066 & 10 & 3 & 0.378 & 0.00114 & 10 & 3 & 0.689 & 0.00171 \\
\hline P25 & P. littoralis & 10 & 1 & - & - & 10 & 1 & - & - & 10 & 2 & 0.200 & 0.00029 \\
\hline P26 & P. littoralis & 10 & 1 & - & - & 10 & 1 & - & - & 10 & 2 & 0.200 & 0.00029 \\
\hline $\mathrm{P} 27$ & P. littoralis & 10 & 4 & 0.778 & 0.00548 & 10 & 4 & 0.733 & 0.00238 & 10 & 4 & 0.733 & 0.00178 \\
\hline P28 & P. littoralis & 10 & 1 & - & - & 10 & 1 & - & - & 10 & 2 & 0.467 & 0.00136 \\
\hline P29 & P. littoralis & 10 & 5 & 0.756 & 0.00208 & 10 & 1 & - & - & 10 & 2 & 0.467 & 0.00136 \\
\hline P30 & P. littoralis & 5 & 3 & 0.700 & 0.00329 & 5 & 3 & 0.800 & 0.00206 & - & - & - & - \\
\hline P33 & P. acarnanica & 10 & 4 & 0.533 & 0.00164 & 10 & 2 & 0.200 & 0.00041 & 10 & 1 & - & - \\
\hline P34 & P. acarnanica & 10 & 1 & - & - & 10 & 1 & - & - & 10 & 1 & - & - \\
\hline P35 & P. semirugata & 5 & 3 & 0.700 & 0.00165 & 5 & 3 & 0.700 & 0.00206 & 5 & 1 & - & - \\
\hline P36 & P. semirugata & 10 & 7 & 0.911 & 0.00581 & 10 & 3 & 0.378 & 0.00206 & 10 & 1 & - & - \\
\hline P37 & P. semirugata & 11 & 8 & 0.927 & 0.00847 & 10 & 4 & 0.711 & 0.00544 & 11 & 1 & - & - \\
\hline P38 & P. semirugata & 10 & 9 & 0.978 & 0.00662 & 10 & 6 & 0.844 & 0.00713 & 10 & 1 & - & - \\
\hline P39 & P. semirugata & 10 & 1 & - & - & 10 & 2 & 0.200 & 0.00041 & 10 & 2 & 0.200 & 0.00029 \\
\hline
\end{tabular}



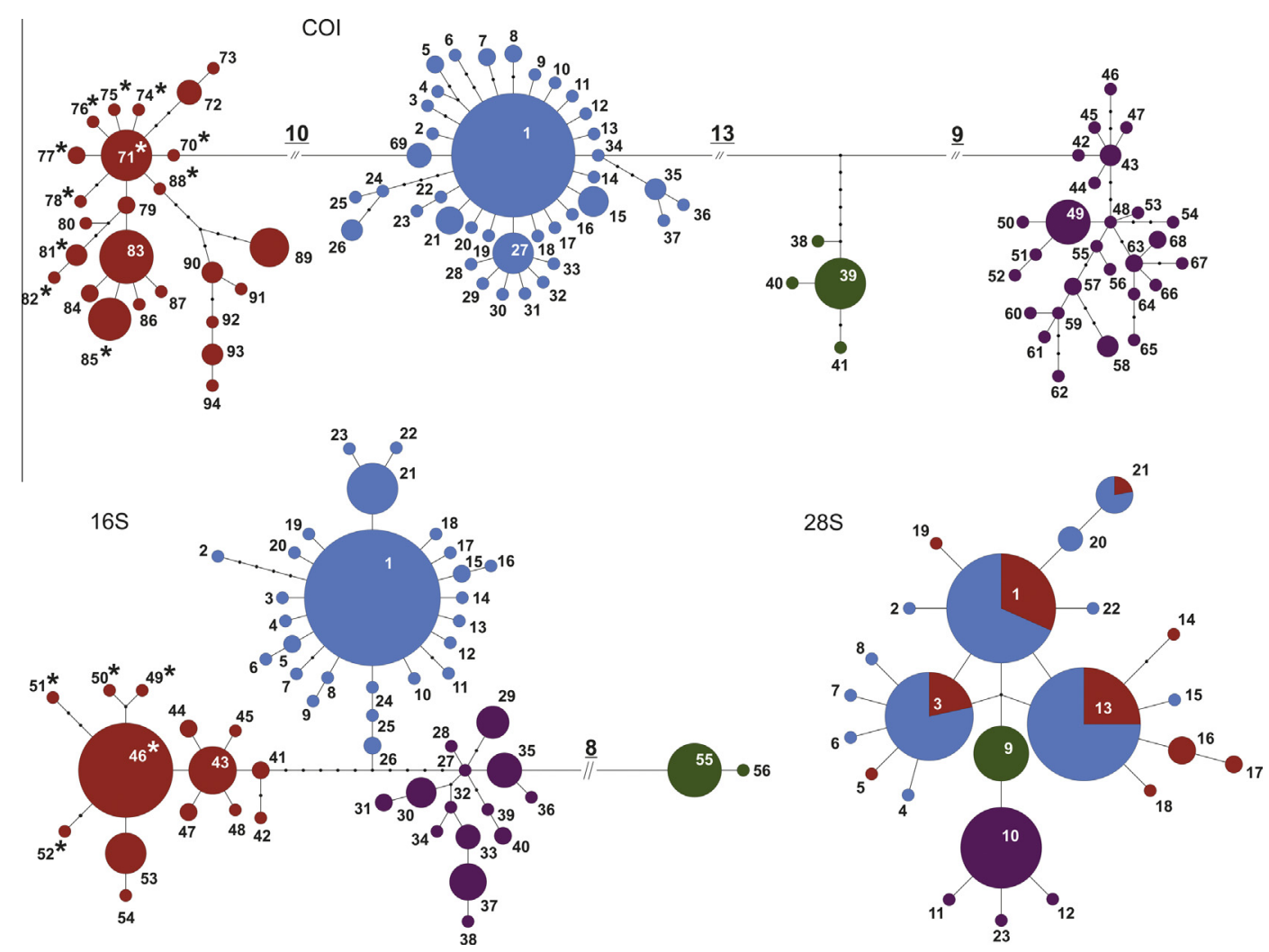

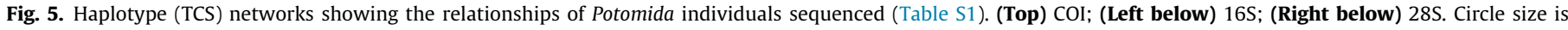

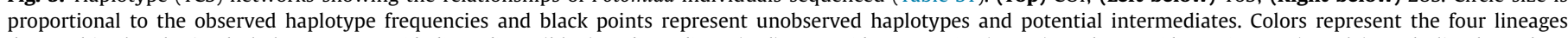

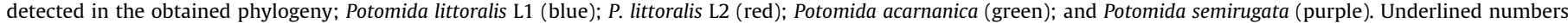

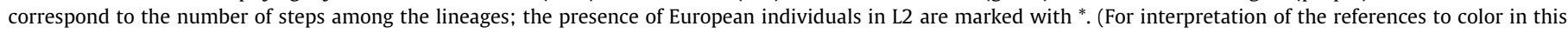
figure legend, the reader is referred to the web version of this article.)

1852) and $P$. tracheae (Kobelt, 1895), P. semirugata (Lamarck, 1819) is the oldest. Hence, following the priority principle, the name $P$. semirugata is here applied.

According to the Bayesian analysis, Potomida probably started radiating during the upper Miocene (8.1 Mya) in which the two major Potomida clades (i.e. western and eastern Mediterranean) emerged. Subsequently, two diversification events occurred more or less contemporaneously devising the current four major lineages. These events occurred at the Miocene-Pliocene transition, closely overlapping with the MSC (5.9-5.3 Mya) (Krijgsman et al., 1999), which indicates the range shifts occurring at the time, might be responsible for these divergences. Such deep divergences also suggest the existence of distinct species, rejecting the monotypic status of the genus.

\subsection{Genetic differences across the Mediterranean geographic discontinuities}

\subsubsection{Western Mediterranean}

The western Mediterranean clade recovered in the phylogeny, and corresponding to $P$. littoralis, is further divided in two lineages (L1 and L2, Fig. 3). Opposite patterns of within-lineage demographic changes were observed. L1 revealed to be very shallow with no clear phylogeographic pattern being observed in Iberia and in France. Both mtDNA gene networks show star-like patterns of connectivity between haplotypes providing support for a recent population expansion in this lineage (Fig. 5). The mismatch analysis and neutrality tests also support a demographic expansion of L1 in Southwest Europe (Table 1; Fig. 6). Therefore, the origin of this lineage was very likely Iberia followed by a population bottleneck event and a posterior expansion. These results are in line with the southern refugia hypothesis followed by post-glacial expansion (Hewitt, 1999).

In contrast, no genetic signal of demographic expansion was observed for L2 (Table 1; Fig. 6). This suggests that in this lineage a series of small relict populations might have existed surviving the successive Quaternary glaciations in isolated refugia, without a detectable subsequent expansion. L2 encompasses all the North African haplotypes but is also present in North-Western Iberia and the Atlantic French river basins. In fact, in the populations from the Douro and Loire basins, each containing both mitochondrial lineages in sympatry, $60 \%$ of the individuals fall into L1 and $40 \%$ into L2. Notwithstanding, the results suggest a possible relatively recent South-North expansion of L2, as it has higher levels of genetic variation in North Africa populations than in Southwestern Europe (Tables 1 and 2). Under this scenario, we would expect that North Africa was the center of origin of this lineage.

We propose and discuss three hypotheses to explain the unexpected phylogeographic pattern described above. In the first, L2 might have existed throughout the entire species distribution, i.e. Southwestern Europe and North Africa, but due to the Pliocene climate changes, it became extirpated in most of its European range. Thus, the shrinking and fluctuating population sizes (Fig. 6) resulted in a loss of ancestral diversity via population bottlenecks and drift. This pattern of incomplete lineage sorting between the two $P$. littoralis lineages is in our view the most likely to explain the recent break of gene flow between the European and North African populations.

In an alternative scenario, if L2 had reached Iberia from North Africa during the MSC, a substantial genetic divergence would be expected in both sides of the Western Mediterranean, resulting from a vicariance event dating back to the reopening of the Strait. 

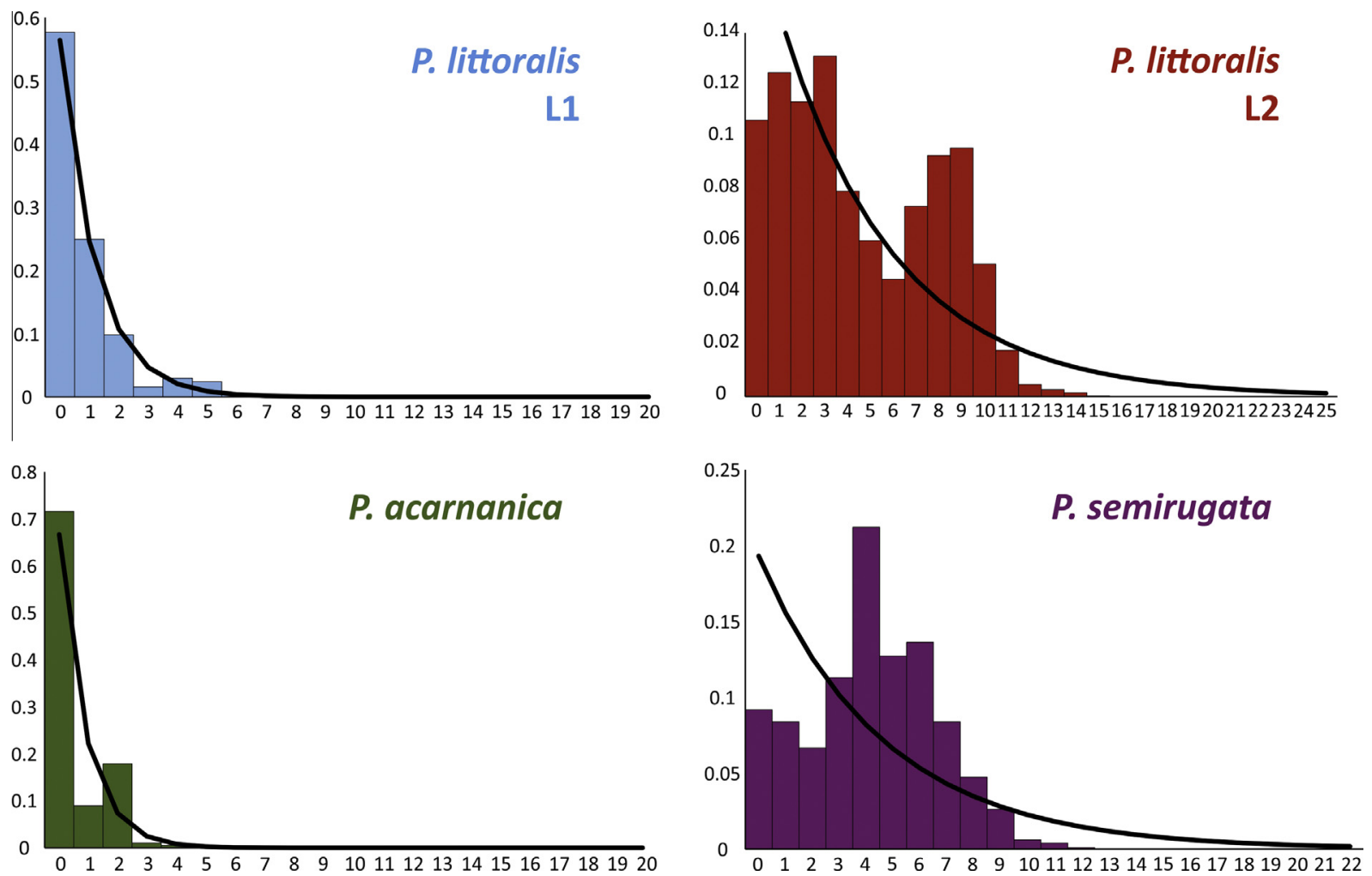

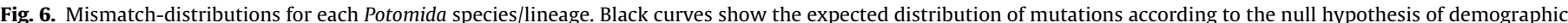

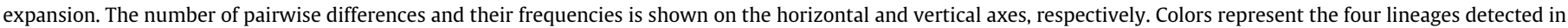

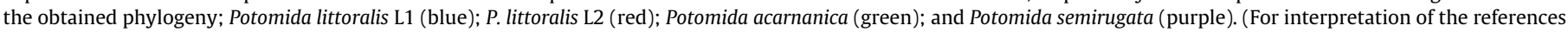
to color in this figure legend, the reader is referred to the web version of this article.)

However, the unexpectedly similarity of both mtDNA and nuclear sequence haplotypes in North African and European populations, and the lack of variation in the European populations in contrast to the North African ones as a whole, suggests that colonization was recent. In addition, L1 and L2 average divergence dates are contemporaneous with the land bridge established during the MSC and this situation raises the hypothesis that the separation of Iberia and North Africa might have caused a vicariance event in this species. Using our calibration framework, the age of the diversification between both lineages is the same as the land bridge. As for the diversification within each of the four main lineages, at least for the extant diversity, it most likely took place well after the end of the MSC.

Finally, and although unlikely, the unexpected geographic pattern of L2 in Europe, i.e., apparently being restricted to Northern Iberia and Atlantic French River basins, can also be explained by the failure of this study in sampling haplotypes that would fall inside L2 in the Southern Iberian basins. Regrettably, the Endangered $P$. littoralis has been declining in recent decades in all Iberian populations (Barea-Azcón et al., 2008; Pérez-Quintero, 2007) and has suffered a major range contraction in France, being extirpated from the north of its former distribution (Prié et al., 2014), which restricts the collection of more specimens.

Within North Africa, the Tunisian haplotypes (in L2) appear in the tip of the COI network (HCOI 90-94, Fig. 5) with a minimum of six mutations to a central haplotype (HCOI 71, Fig. 5) and to the Morocco haplotype (HCOI 71, Fig. 5) found in the individuals from the only sampled endorheic basin (River Ziz - P28, Figs. 2 and 5; Table S1). Interestingly, the mean COI genetic distance between the newly sequenced Moroccan individuals and the previously published Tunisian ones (Khalloufi et al., 2011) is $1.5 \%$, while $2.4 \%$ corresponds to the mean COI genetic distance between the entire L2 and the European L1. These results further add to the evidence of other studies (e.g. amphibians: Recuero et al., 2007; and freshwater mussels, Unio sp.: Khalloufi et al., 2011) suggesting the presence of an important biogeographical barrier between eastern and western Maghreb.

\subsubsection{Eastern Mediterranean}

The east Mediterranean clade contains $P$. acarnanica and $P$. semirugata, which diverge $3 \%$. In Western Greece, $P$. acarnanica is restricted to the southern part of the Ionian Ecoregion, an area well known for its higher endemicity in the Hellenic peninsula (e.g. freshwater fish; Economou et al., 2007). The results from the demographic changes (Table 1, Fig. 6) revealed a recent bottleneck. This could be due to a contraction in the mussel's distribution as the species inhabits relatively small river basins whose lowland river valley habitats were decreased by sea level rise after the last glacial maximum (Perissoratis and Conispoliatis, 2003). On the contrary, its sister species, $P$. semirugata has a wider range through southern Anatolia and the Levant. In addition, the results have shown that this species has the higher haplotype diversity, and both tests of demographic history and mismatch distributions support a scenario of more stable populations. Furthermore, these populations occur in areas with a long history of intra-basin isolation (Heller, 2007) that might help to explain their higher genetic diversity.

The divergence between mtDNA lineages of these species seems likely contemporaneous with the MSC period (5.9-5.3 Mya), while diversification within each lineage took place much after, particularly for P. acarnanica. It is possible that the low diversity observed in this species could be due to recent population reductions and lineage extirpation. This pattern is not seen in P. semirugata. This could be due to the more geographically isolated and fragmented 
riverine habitats in Peninsular Greece (i.e. being more vulnerable to climate-driven extirpations) but it could also mean that Greece was colonized (or re-colonized) from Anatolia during the MSC, thus leading to a more extended evolutionary lag time.

This pattern of "oriental origin" has been observed in freshwater fishes in the Balkans. However, the timing is still controversial, as are processes that have led to the key assemblage components of each biogeographic region (Bănărescu, 2004; Gaubert et al., 2009). The biogeographical boundary of the mid-Aegean trench separating Anatolia from Southern Greece is long established (Poulakakis et al., 2015; Zogaris et al., 2009), but dispersal of freshwater organisms may have occurred either during the MSC or even at an earlier land contact event. Tsigenopoulos et al. (2003) hypothesised that during the MSC a network of interconnected rivers facilitated dispersal of the cyprinid genus Luciobarbus across the dried Mediterranean. Indeed, Luciobarbus exists in Southern Turkey, Eastern Greece and Western Greece, and different species on both sides of the Aegean are genetically very close (Geiger et al., 2014). Therefore, the MSC is the most likely hypothesis within our dating framework (Fig. 4). The alternative scenario is a colonization during the connection of the Hellenic Peninsula and Anatolia in the upper Miocene, i.e., before the MSC (Economou et al., 2007; Poulakakis et al., 2015). However, this seems unlikely since the age of this event falls outside the confidence interval for the semirugata-acarnanica divergence. Even if a common ancestor carried out the colonization, one could expect a higher diversity in Greece.

\subsection{Comparison with other Mediterranean freshwater mussels and conservation implications}

Classic "refugia within refugia" phylogeographic patterns (Gómez and Lunt, 2007), with a nearly or complete lack of mtDNA admixture among populations, have been described in several taxa for Iberia, Maghreb, Balkans, Anatolia and the Middle East (e.g. Schmitt, 2007). However, examples from freshwater mussels are still scarce in Europe, scarcer in North Africa, and absent for the Eastern Mediterranean region. The lack of genetic differentiation among Southwest European river basins, here obtained for $P$. littoralis L1, has been recently reported for another freshwater mussel species in Iberia (Unio delphinus Spengler, 1793; Froufe et al., 2016a). On the other hand, several allopatric distinct lineages were detected for another freshwater mussel in Iberia (Anodonta anatina (Linnaeus, 1758); Froufe et al., 2014). In the Maghreb region, while no genetic differentiation was observed for Unio foucauldianus Pallary, 1936 populations across its range (Froufe et al., 2016a) in Potomida two possible refugia were here detected with $1.5 \%$ (COI) genetic divergence between them (i.e. Moroccan and Tunisian populations). Unfortunately, there are no molecular studies using freshwater mussels as target organisms in the Balkans and Turkey, which precludes further considerations regarding the presence of diversity sub-centers for these taxa in the area.

Despite having a Circum-Mediterranean distribution and being one of the most endangered freshwater bivalves in Europe, little was known about intraspecific variation in Potomida. The present study recognized Iberia, Maghreb, Southwestern Greece and Southern Turkey as its main four "classic refugia". Thus, they should constitute priority areas of conservation for Potomida species. This is especially urgent given the threats posed by the extensive environmental changes occurring in the Mediterranean region. Additionally, since the last IUCN global assessment for $P$. littoralis (Endangered) included the three Potomida species now recognized, they should be re-evaluated individually, probably giving each a heightened threat status. P. littoralis (L1 + L2) for instance has suffered a strong decline with a 75\% population decrease in its European range (Lopes-Lima et al., 2014). The Moroccan populations are also declining due to the dramatic decrease of water quantity and quality in several Moroccan river basins (Sousa et al., 2016). As for P. acarnanica, it is classified as highly threatened since it revealed a very low genetic diversity and presents a restricted distribution, known only from two basins (Pamisos and Acheloos). Distinct pressures (e.g. dams, artificial riverbed desiccation, river quarrying, urban, agricultural and industrial pollution, and other anthropogenic pressures; Skoulikidis et al., 2009) affect both basins. Finally, and although we could still detect high genetic diversity patterns within $P$. semirugata, its distribution has been declining since most rivers in Southern Turkey have been dramatically affected by urbanization and agriculture, including the desiccation of entire lakes and wetland areas (e.g. Avlan, Söğüt, Karagöl, Hula Lakes; Ereğli and Amik wetlands; Seddon et al., 2014).

\subsection{Conclusions and future directions}

This study presents for the first time a geographically comprehensive dataset of Potomida, including representatives from most of its known distribution in one multilocus phylogenetic study, updating the knowledge on local biodiversity and providing useful data for taxonomy, ecology, and conservation.

Future research should include specimens from potential missing key biogeographical regions (e.g. the Arax river basin, to verify the phylogenetic and taxonomic status of $P$. l. komarowi (O. Boettger, 1880)) or refugia-within-refugia (e.g. sampling in Algeria, to map where the two North African observed haplogroups meet); the use of faster evolving markers to study present connectivity (e.g. Microsatellite markers already developed for Potomida littoralis; Froufe et al., 2013); and assess the male mtDNA genetic structuration for a stronger evolutionary signal.

\section{Acknowledgements}

The authors wish to thank the two anonymous reviewers for helpful remarks and suggestions that improved the quality of the manuscript. Financial support was provided by Portuguese Foundation for Science and Technology (FCT) Grant to EF (SFRH/ BPD/108445/2015), to DVG (SFRH/BD/78402/2011) and Project (PTDC/AAC-AMB/117688/2010) as well as by Biotope, Conchological Society of Great Britain and Ireland, and the Mohamed bin Zayed Species Conservation Fund (Reference 15256799). We thank José María Irurita, José Miguel Barea Azcón, Keiko Nakamura, Pablo Redin and Esther Penin for all their help during the Spanish field campaigns, Benjamin Adam, Panier Cucherat, Quentin Molina and Laurent Philippe for their help in sampling French specimens, and Dan Graf for providing us with the exact locations of previously sequenced animals. Official capture and sampling licenses were issued by the following agencies: (1) Junta de Castilla y León (Consejería de Fomento y Medio Ambiente EP/ CYL/331/2012, de 17 de Abril de 2012); (2) Junta de Andalucia (Consejería de Medio Ambiente-SGYB/FOA/AFR/SFS, de 17 de Julio de 2012); (3) Gobierno de Aragón (Dirección General de Conservación del Medio Natural - 136.071/2012 de 12 de julio de 2012); (4) Université Cadi Ayyad (Faculté des Sciences, Semlalia, Marrakech, Maroc); (5) Hellenic Ministry of Agriculture and Institute of Marine Biological Resources and Inland Waters, Hellenic Centre for Marine Research (Greece).

\section{Appendix A. Supplementary material}

Supplementary data associated with this article can be found, in the online version, at http://dx.doi.org/10.1016/j.ympev.2016.04. 030 . 


\section{References}

Araujo, R., Gómez, I., Machordom, A., 2005. The identity and biology of Unio mancus Lamarck, 1819 (=U. elongatulus) (Bivalvia: Unionidae) in the Iberian Peninsula. J. Molluscan Stud. 71, 25-31. http://dx.doi.org/10.1093/mollus/eyi002.

Araujo, R., Toledo, C., Machordom, A., 2009. Redescription of Unio gibbus Spengler 1793, A West Palaearctic freshwater mussel with hookless glochidia. Malacologia 51, 131-141. http://dx.doi.org/10.4002/040.051.0109.

Bănărescu, P.M., 2004. Distribution Pattern of the Aquatic Fauna of the Balkan Peninsula. In: Griffiths, H.I., Kryštufek, B., Reed, J.M. (Eds.), Balkan Biodiversity. Springer, Netherlands, Dordrecht, pp. 203-217. http://dx.doi.org/10.1007/9781-4020-2854-0.

Barea-Azcón, J., Ballesteros-Duperón, E., Moreno, D., 2008. Libro Rojo de los Invertebrados de Andalucía. Consejería de Medio Ambiente, Junta de Andalucía, Sevilla.

Bianco, P.G., 1990. Potential role of the palaeohistory of the Mediterranean and Paratethys basin on the early dispersal of Europe-Mediterranean freshwater fishes. Ichthyol. Explor. Freshwaters 1, 167-184.

Blondel, J., Aronson, J., Bodiou, J.-Y., Boeuf, G., 2010. The Mediterranean Region: Biological Diversity in Space and Time, second ed. Oxford University Press, Oxford, UK.

Bohlen, J., Slechtová, V., Bogutskaya, N., Freyhof, J., 2006. Across Siberia and over Europe: phylogenetic relationships of the freshwater fish genus Rhodeus in Europe and the phylogenetic position of $R$. sericeus from the River Amur. Mol. Phylogenet. Evol. 40, 856-865. http://dx.doi.org/10.1016/j.ympev.2006.04.020.

Carranza, S., Harris, D.J., Arnold, E.N., Batista, V., Gonzalez de la Vega, J.P., 2006 Phylogeography of the lacertid lizard, Psammodromus algirus, in Iberia and across the Strait of Gibraltar. J. Biogeogr. 33, 1279-1288. http://dx.doi.org/ 10.1111/j.1365-2699.2006.01491.x.

Clement, M., Posada, D., Crandall, K.A., 2000. TCS: a computer program to estimate gene genealogies. Mol. Ecol. 9, 1657-1659. http://dx.doi.org/10.1046/j.1365294x.2000.01020.x

Cuttelod, A., García, N., Abdul Malak, D., Temple, H., Katariya, V., 2008. The Mediterranean: a biodiversity hotspot under threat. In: Vié, J.-C., Hilton-Taylor, C., Stuart, S.N. (Eds.), The 2008 Review of The IUCN Red List of Threatened Species. IUCN, Gland.

Darriba, D., Taboada, G.L., Doallo, R., Posada, D., 2012. JModelTest 2: more models, new heuristics and parallel computing. Nat. Methods 9, 772. http://dx.doi.org 10.1038/nmeth.2109.

Drummond, A.J., Rambaut, A., 2007. BEAST: Bayesian evolutionary analysis by sampling trees. BMC Evol. Biol. 7, 214. http://dx.doi.org/10.1186/1471-2148-7-214.

Drummond, A.J., Ho, S.Y.W., Phillips, M.J., Rambaut, A., 2006. Relaxed phylogenetics and dating with confidence. PLoS Biol. 4, e88. http://dx.doi.org/10.1371/journal. pbio.0040088.

Economou, A.N., Giakoumi, S., Vardakas, L., Barbieri, R., Stoumboudi, M.T., Zogaris S., 2007. The freshwater ichthyofauna of Greece - an update based on a hydrographic basin survey. Mediterr. Mar. Sci. 8, 91-166. http://dx.doi.org/ $10.12681 / \mathrm{mms} .164$.

Elderkin, C.L., Christian, A.D., Metcalfe-Smith, J.L., Berg, D.J., 2008. Population genetics and phylogeography of freshwater mussels in North America, Elliptio dilatata and Actinonaias ligamentina (Bivalvia: Unionidae). Mol. Ecol. 17, 21492163. http://dx.doi.org/10.1111/j.1365-294X.2008.03745.x.

Excoffier, L., Lischer, H.E.L., 2010. Arlequin suite ver 3.5: a new series of programs to perform population genetics analyses under Linux and Windows. Mol. Ecol. Resour. 10, 564-567. http://dx.doi.org/10.1111/j.1755-0998.2010.02847.x.

Feliner, G.N., 2011. Southern European glacial refugia: a tale of tales. Taxon 60, 365372.

Fonseca, M.M., Brito, J.C., Paulo, O.S., Carretero, M.A., Harris, D.J., 2009. Systematic and phylogeographical assessment of the Acanthodactylus erythrurus group (Reptilia: Lacertidae) based on phylogenetic analyses of mitochondrial and nuclear DNA. Mol. Phylogenet. Evol. 51, 131-142. http://dx.doi.org/10.1016/j. ympev.2008.11.021.

Fromhage, L., Vences, M., Veith, M., 2004. Testing alternative vicariance scenarios in Western Mediterranean discoglossid frogs. Mol. Phylogenet. Evol. 31, 308-322. http://dx.doi.org/10.1016/j.ympev.2003.07.009.

Froufe, E., Sobral, C., Teixeira, A., Lopes, A., Sousa, R., Varandas, S., Lopes-Lima, M., 2013. Development and multiplexing of microsatellite loci for the near threatened freshwater mussel Potomida littoralis (Cuvier, 1798) using 454 sequencing. Aquat. Conserv. Mar. Freshw. Ecosyst. 23, 619-623. http://dx.doi. org/10.1002/aqc.2335.

Froufe, E., Sobral, C., Teixeira, A., Sousa, R., Varandas, S.C., Aldridge, D., Lopes-Lima, M., 2014. Genetic diversity of the pan-European freshwater mussel Anodont anatina (Bivalvia: Unionoida) based on CO1: new phylogenetic insights and implications for conservation. Aquat. Conserv. Mar. Freshw. Ecosyst. 24, 561 574. http://dx.doi.org/10.1002/aqc.2456.

Froufe, E., Gonçalves, D.V., Teixeira, A., Sousa, R., Varandas, S., Ghamizi, M., Zieritz, A., Lopes-Lima, M., 2016a. Who lives where? Molecular and morphometric analyses clarify which Unio species (Unionida, Mollusca) inhabit the southwestern Palearctic region. Org. Divers. Evol. http://dx.doi.org/10.1007/ s13127-016-0262-X.

Froufe, E., Gan, H.M., Lee, Y.P., Carneiro, J., Varandas, S., Teixeira, A., Zieritz, A., Sousa, R. Lopes-Lima, M., 2016b. The male and female complete mitochondria genome sequences of the Endangered freshwater mussel Potomida littoralis (Cuvier, 1798) (Bivalvia: Unionidae). Mitochondrial DNA. http://dx.doi.org $10.3109 / 19401736.2015 .1074223$.
Fu, Y.X., 1997. Statistical tests of neutrality of mutations against population growth, hitchhiking and background selection. Genetics 147, 915-925.

García-París, M., Alcobendas, M., Buckley, D., Wake, D.B., 2003. Dispersal of Viviparity across Contact Zones in Iberian Populations of Fire Salamanders (Salamandra) Inferred From Discordance of Genetic and Morphological Traits. Evolution (N.Y) 57, 129-143. http://dx.doi.org/10.1111/j.0014-3820.2003. tb00221.x.

Gaubert, P., Denys, G., Oberdorff, T., 2009. Genus-level supertree of Cyprinidae (Actinopterygii: Cypriniformes), partitioned qualitative clade support and test of macro-evolutionary scenarios. Biol. Rev. 84, 653-689. http://dx.doi.org/ 10.1111/j.1469-185X.2009.00091.x.

Geiger, M.F., Herder, F., Monaghan, M.T., Almada, V., Barbieri, R., Bariche, M., Berrebi, P., Bohlen, J., Casal-Lopez, M., Delmastro, G.B., Denys, G.P.J., Dettai, A., Doadrio, I., Kalogianni, E., Kärst, H., Kottelat, M., Kovačić, M., Laporte, M., Lorenzoni, M., Marčić, Z., Özuluğ, M., Perdices, A., Perea, S., Persat, H., Porcelotti, S., Puzzi, C., Robalo, J., Šanda, R., Schneider, M., Šlechtová, V., Stoumboudi, M., Walter, S., Freyhof, J., 2014. Spatial heterogeneity in the Mediterranean Biodiversity Hotspot affects barcoding accuracy of its freshwater fishes. Mol. Ecol. Resour. 14, 1210-1221. http://dx.doi.org/10.1111/1755-0998.12257.

Geist, J., Geismar, J., Kuehn, R., 2010. Isolation and characterization of the first microsatellite markers for the endangered swan mussel Anodonta cygnea $\mathrm{L}$. (Bivalvia: Unionoidea). Conserv. Genet. 11, 1103-1106. http://dx.doi.org/ 10.1007/s10592-009-9889-x.

Gernhard, T., 2008. New analytic results for speciation times in neutral models. Bull. Math. Biol. 70, 1082-1097. http://dx.doi.org/10.1007/s11538-007-9291-0.

Gómez, A., Lunt, D., 2007. Refugia within refugia: patterns of phylogeographic concordance in the Iberian Peninsula. In: Weiss, S., Ferrand, N. (Eds.), Phylogeography in Southern European Refugia: Evolutionary Perspectives on the Origin and Conservation of European Biodiversity. Springer, Netherlands, Dordrecht, pp. 155-188. http://dx.doi.org/10.1007/1-4020-4904-8.

Graf, D.L., 2010. Funeral for the nouvelle école - iana generic names introduced for freshwater mussels (Mollusca: Bivalvia: Unionoida). Proc. Acad. Nat. Sci. Philadelphia 159, 1-23. http://dx.doi.org/10.1635/053.159.0101.

Guindon, S., Gascuel, O., 2003. A simple, fast, and accurate algorithm to estimate large phylogenies by maximum likelihood. Syst. Biol. 52, 696-704. http://dx. doi.org/10.1080/10635150390235520.

Haas, F., 1969. Superfamilia Unionacea. Das Tierrich, vol. 88. Walter de Gruyter, Berlin.

Hall, T., 1999. BioEdit: a user-friendly biological sequence alignment editor and analysis program for Windows 95/98/NT. Nucl. Acids Symp. Ser. 41, 95-98.

Heller, J., 2007. A historic biogeography of the aquatic fauna of the Levant. Biol. J. Linn. Soc. 92, 625-639. http://dx.doi.org/10.1111/j.1095-8312.2007.00850.x.

Hewitt, G.M., 1999. Post-glacial re-colonization of European biota. Biol. J. Linn. Soc. 68, 87-112. http://dx.doi.org/10.1111/j.1095-8312.1999.tb01160.x.

Hoeh, W.R., Stewart, D.T., Sutherland, B.W., Zouros, E., 1996. Multiple Origins of Gender-Associated Mitochondrial DNA Lineages in Bivalves (Mollusca: Bivalvia). Evolution 50, 2276-2286. http://dx.doi.org/10.2307/2410697.

Khalloufi, N., Toledo, C., Machordom, a., Boumaiza, M., Araujo, R., 2011. The unionids of Tunisia: taxonomy and phylogenetic relationships, with redescription of Unio ravoisieri Deshayes, 1847 and $U$. durieui Deshayes, 1847. J. Molluscan Stud. 77, 103-115. http://dx.doi.org/10.1093/mollus/eyq046.

Krijgsman, W., Hilgen, F.J., Raffi, I., Sierro, F.J., Wilson, D.S., 1999. Chronology, Causes and Progression of the Messinian Salinity Crisis, vol. 400, pp. 652-655. http:// dx.doi.org/10.1038/23231.

Lopes-Lima, M., Prié, V., Seddon, M.B., 2014. Potomida littoralis. The IUCN Red List of Threatened Species. Version 2015.4. <http://www.iucnredlist.org/> (accessed 15 January 2016).

Lopes-Lima, M., Sousa, R., Teixeira, A., Varandas, S., Riccardi, N., Aldridge, D.C. Froufe, E., 2016a. Newly developed microsatellite markers for the pan-European duck mussel, Anodonta anatina: revisiting the main mitochondrial lineages. Aquat. Conserv. Mar. Freshw. Ecosyst. 26, 307-318. http://dx.doi.org/10.1002/ aqc. 2575 .

Lopes-Lima, M., Sousa, R., Geist, J., Aldridge, D.C., Araujo, R., Bergengren, J., Bespalaya, Y., Bódis, E., Burlakova, L., Van Damme, D., Douda, K., Froufe, E., Georgiev, D. Gumpinger, C. Karatayev, A., Kebapç, Ü., Killeen, I., Laitner, J. Larsen, B.M., Lauceri, R., Legakis, A., Lois, S., Lundberg, S., Moorkens, E., Motte, G., Nagel, K.-O., Ondina, P., Outeiro, A., Paunovic, M., Prié, V., von Proschwitz, T., Riccardi, N., Rudzīte, M., Rudzītis, M., Scheder, C., Seddon, M., Sereflișan, H. Simić, V., Sokolova, S., Stoeckl, K., Taskinen, J., Teixeira, A., Thielen, F., Trichkova, T., Varandas, S., Vicentini, H., Zajac, K., Zajac, T., Zogaris, S., 2016b. Conservation status of freshwater mussels in Europe: state of the art and future challenges. Biol. Rev. http://dx.doi.org/10.1111/brv.12244.

Machordom, A., Araujo, R., Erpenbeck, D., Ramos, M.-Á., 2003. Phylogeography and conservation genetics of endangered European Margaritiferidae (Bivalvia: Unionoidea). Biol. J. Linn. Soc. 78, 235-252. http://dx.doi.org/10.1046/j.10958312.2003.00158.x.

Mason-Gamer, R.J., Kellogg, E.A., 1996. Testing for phylogenetic conflict among molecular data sets in the tribe Triticeae (Gramineae). Syst. Biol. 45, 524-545. http://dx.doi.org/10.1093/sysbio/45.4.524.

Médail, F., Diadema, K., 2009. Glacial refugia influence plant diversity patterns in the Mediterranean Basin. J. Biogeogr. 36, 1333-1345. http://dx.doi.org/10.1111/ j.1365-2699.2008.02051.x.

Miraldo, A., Hewitt, G.M., Paulo, O.S., Emerson, B.C., 2011. Phylogeography and demographic history of Lacerta lepida in the Iberian Peninsula: multiple refugia, range expansions and secondary contact zones. BMC Evol. Biol. 11, 170. http:// dx.doi.org/10.1186/1471-2148-11-170. 
Mock, K.E., Brim Box, J.C., Chong, J.P., Furnish, J., Howard, J.K., 2013. Comparison of population genetic patterns in two widespread freshwater mussels with contrasting life histories in western North America. Mol. Ecol. 22, 6060-6073. http://dx.doi.org/10.1111/mec.12557.

Myers, N., Mittermeier, R.A., Mittermeier, C.G., da Fonseca, G.A., Kent, J., 2000. Biodiversity hotspots for conservation priorities. Nature 403, 853-858. http:// dx.doi.org/10.1038/35002501.

Nagel, K.-O., Badino, G., Alessandria, B., 1996. Population Genetics of European Anodontinae (Bivalvia: Unionidae). J. Molluscan Stud. 62, 343-357. http://dx. doi.org/10.1093/mollus/62.3.343.

Naimo, T.J., Damschen, E.D., Rada, R.G., Monroe, E.M., 1998. Nonlethal evaluation of the physiological health of unionid mussels: methods for biopsy and glycogen analysis. J. North Am. Benthol. Soc. 17, 121-128.

Nei, M., 1987. Molecular Evolutionary Genetics. Columbia University Press, New York.

Nei, M., Tajima, F., 1981. DNA polymorphism detectable by restriction endonucleases. Genetics 97, 145-163.

Palumbi, S.R., Martin, A.P., Romano, S., McMillan, W.O., Stice, L., Grabowski, G., 1991. The Simple Fool's Guide to PCR, Version 2.0. Published and distributed by the authors, Honolulu.

Paulo, O.S., Pinheiro, J., Miraldo, A., Bruford, M.W., Jordan, W.C., Nichols, R.A., 2008. The role of vicariance vs. dispersal in shaping genetic patterns in ocellated lizard species in the western Mediterranean. Mol. Ecol. 17, 1535-1551. http:// dx.doi.org/10.1111/j.1365-294X.2008.03706.x.

Pérez-Quintero, J.C., 2007. Diversity, habitat use and conservation of freshwater molluscs in the lower Guadiana River basin (SW Iberian Peninsula). Aquat. Conserv. Mar. Freshw. Ecosyst. 17, 485-501. http://dx.doi.org/10.1002/aqc.796.

Perissoratis, C., Conispoliatis, N., 2003. The impacts of sea-level changes during latest Pleistocene and Holocene times on the morphology of the Ionian and Aegean seas (SE Alpine Europe). Mar. Geol. 196, 145-156. http://dx.doi.org/ 10.1016/S0025-3227(03)00047-1.

Poulakakis, N., Kapli, P., Lymberakis, P., Trichas, A., Vardinoyiannis, K., Sfenthourakis, S., Mylonas, M., 2015. A review of phylogeographic analyses of animal taxa from the Aegean and surrounding regions. J. Zool. Syst. Evol. Res. 53, 18-32. http://dx.doi.org/10.1111/jzs.12071.

Prié, V., Puillandre, N., 2014. Molecular phylogeny, taxonomy, and distribution of French Unio species (Bivalvia, Unionidae). Hydrobiologia 735, 95-110. http:// dx.doi.org/10.1007/s10750-013-1571-0.

Prié, V., Molina, Q., Gamboa, B., 2014. French naiad (Bivalvia: Margaritiferidae, Unionidae) species distribution models: Prediction maps as tools for conservation. Hydrobiologia 735, 81-94. http://dx.doi.org/10.1007/s10750013-1597-3.

Rambaut, A., Suchard, M.A., Xie, D., Drummond, A.J., 2014. Tracer v1. 6 Computer Program and Documentation Distributed by the Author. <http://beast.bio.ed.ac. uk/Tracer>.

Ramos-Onsins, S.E., Rozas, J., 2002. Statistical properties of new neutrality tests against population growth. Mol. Biol. Evol. 19, 2092-2100. http://dx.doi.org/ 10.1093/oxfordjournals.molbev.a004034.

Recuero, E., Iraola, A., Rubio, X., Machordom, A., García-París, M., 2007. Mitochondrial differentiation and biogeography of Hyla meridionalis (Anura: Hylidae): an unusual phylogeographical pattern. J. Biogeogr. 34, 1207-1219. http://dx.doi.org/10.1111/j.1365-2699.2007.01688.x.

Rogers, A., Harpending, H., 1992. Population growth makes waves in the distribution of pairwise genetic differences. Mol. Biol. Evol. 9, 552-569.

Ronquist, F., Teslenko, M., van der Mark, P., Ayres, D.L., Darling, A., Hohna, S., Larget, B., Liu, L., Suchard, M.A., Huelsenbeck, J.P., 2012. MrBayes 3.2: effective Bayesian phylogenetic inference and model choice across a large model space. Syst. Biol. 61, 539-542.

Rouchy, J.M., Caruso, A., 2006. The Messinian salinity crisis in the Mediterranean basin: a reassessment of the data and an integrated scenario. Sediment. Geol. 188-189, 35-67. http://dx.doi.org/10.1016/j.sedgeo.2006.02.005.

Rozas, J., Rozas, R., 1995. DnaSP, DNA sequence polymorphism: an interactive program for estimating population genetics parameters from DNA sequence data. Bioinformatics 11, 621-625. http://dx.doi.org/10.1093/bioinformatics/ 11.6.621.

Sambrook, J., Fritsch, E.F., Maniatis, T., 1989. Molecular Cloning: a Laboratory Manual. Cold Harbor Spring Press, New York.

Schmitt, T., 2007. Molecular biogeography of Europe: pleistocene cycles and postglacial trends. Front. Zool. 4, 11. http://dx.doi.org/10.1186/1742-9994-411.

Schmitt, T., Hewitt, G.M., Müller, P., 2006. Disjunct distributions during glacial and interglacial periods in mountain butterflies: Erebia epiphron as an example. J. Evol. Biol. 19, 108-113. http://dx.doi.org/10.1111/j.1420-9101.2005.00980.x.

Seddon, M.B., Kebapçı, Ü., Lopes-Lima, M., Damme, D. van, Smith, K.G., 2014. Freshwater mollusks. In: Smith, K.G., Barrios, V., Darwall, W.R.T., Numa, C. (Eds.), The Status and Distribution of Freshwater Biodiversity in the Eastern
Mediterranean. Cambridge, UK, Malaga, Spain and Gland, Switzerland, pp. 4356.

Skoulikidis, N., Economou, A.N., Gritzalis, K.C., Zogaris, S., 2009. Rivers of the Balkans. In: Tockner, K., Uehlinger, U., Robinson, C.T. (Eds.), Rivers of Europe. Elsevier Academic Press, Amsterdam, pp. 421-466.

Smith, D.G., 2001. Systematics and distribution of the recent margaritiferidae. In: Bauer, G., Wächtler, K. (Eds.), Ecology and Evolution of the Freshwater Mussels Unionoida. Ecological Studies. Springer, Berlin, Heidelberg, pp. 33-49. http://dx. doi.org/10.1007/978-3-642-56869-5.

Sotiropoulos, K., Eleftherakos, K., Dzukić, G., Kalezić, M.L., Legakis, A., Polymeni, R. M., 2007. Phylogeny and biogeography of the alpine newt Mesotriton alpestris (Salamandridae, Caudata), inferred from mtDNA sequences. Mol. Phylogenet. Evol. 45, 211-226. http://dx.doi.org/10.1016/j.ympev.2007.03.012.

Sousa, R., Dias, S., Guilhermino, L., Antunes, C., 2008. Minho River tidal freshwater wetlands: threats to faunal biodiversity. Aquat. Biol. 3, 237-250.

Sousa, R., Amorim, Â., Froufe, E., Varandas, S., Teixeira, A., Lopes-Lima, M., 2015 Conservation status of the freshwater pearl mussel Margaritifera margaritifera in Portugal. Limnol. - Ecol. Manag. Inl. Waters 50, 4-10. http://dx.doi.org/10.1016/ j.limno.2014.07.004.

Sousa, R., Varandas, S., Teixeira, A., Ghamizi, M., Froufe, E., Lopes-Lima, M., 2016. Pearl mussels (Margaritifera marocana) in Morocco: Conservation status of the rarest bivalve in African fresh waters. Sci. Total Environ. 547, 405-412. http:// dx.doi.org/10.1016/j.scitotenv.2016.01.003.

Steinfartz, S., Veith, M., Tautz, D., 2000. Mitochondrial sequence analysis of Salamandra taxa suggests old splits of major lineages and postglacial recolonizations of Central Europe from distinct source populations of Salamandra salamandra. Mol. Ecol. 9, 397-410. http://dx.doi.org/10.1046/ j.1365-294x.2000.00870.x.

Stöck, M., Dufresnes, C., Litvinchuk, S.N., Lymberakis, P., Biollay, S., Berroneau, M., Borzée, A., Ghali, K., Ogielska, M., Perrin, N., 2012. Cryptic diversity among Western Palearctic tree frogs: postglacial range expansion, range limits, and secondary contacts of three European tree frog lineages (Hyla arborea group). Mol. Phyl. Evol 65, 1-9. http://dx.doi.org/10.1016/j.ympev.2012.05.014.

Taberlet, P., Fumagalli, L., Wust-Saucy, A.-G., Cosson, J.-F., 1998. Comparative phylogeography and postglacial colonization routes in Europe. Mol. Ecol. 7 453-464. http://dx.doi.org/10.1046/j.1365-294x.1998.00289.x.

Tajima, F., 1989. Statistical method for testing the neutral mutation hypothesis by DNA polymorphism. Genetics 123, 585-595.

Tamura, K., Stecher, G., Peterson, D., Filipski, A., Kumar, S., 2013. MEGA6: molecular evolutionary genetics analysis version 6.0. Mol. Biol. Evol. 30, 2725-2729. http://dx.doi.org/10.1093/molbev/mst197.

Tsigenopoulos, C.S., Durand, J.D., Ünlü, E., Berrebi, P., 2003. Rapid radiation of the Mediterranean Luciobarbus species (Cyprinidae) after the Messinian salinity crisis of the Mediterranean Sea, inferred from mitochondrial phylogenetic analysis. Biol. J. Linn. Soc. 80, 207-222. http://dx.doi.org/10.1046/j.10958312.2003.00237.x.

Veith, M., Schmidtler, J.F., Kosuch, J., Baran, I., Seitz, A., 2003. Palaeoclimatic changes explain Anatolian mountain frog evolution: a test for alternating vicariance and dispersal events. Mol. Ecol. 12, 185-199. http://dx.doi.org/10.1046/j.1365294X.2003.01714.x.

Walker, J.M., Curole, J.P., Wade, D.E., Chapman, E.G., Bogan, A.E., Watters, G.T., Hoeh, W.R., 2006. Taxonomic Distribution and Phylogenetic Utility of GenderAssociated Mitochondrial Genomes in the Unionoida (Bivalvia). Malacologia 48, 265-282.

Walker, J.M., Bogan, A.E., Bonfiglio, E.A., Campbell, D.C., Christian, A.D., Curole, J.P., Harris, J.L., Wojtecki, R.J., Hoeh, W.R., 2007. Primers for amplifying the hypervariable, male-transmitted COII-COI junction region in amblemine freshwater mussels (Bivalvia: Unionoidea: Ambleminae): primer note. Mol Ecol. Notes 7, 489-491. http://dx.doi.org/10.1111/j.1471-8286.2006.01630.x.

Whiting, M.F., 2002. Mecoptera is paraphyletic: multiple genes and phylogeny of Mecoptera and Siphonaptera. Zool. Scr. 31, 93-104. http://dx.doi.org/10.1046/ j.0300-3256.2001.00095.x.

Yule, G.U., 1925. A Mathematical theory of evolution, based on the conclusions of Dr. J.C. Willis, F.R.S. Philos. Trans. Roy. Soc. Lond. B. Biol. Sci. 213, 21-87.

Zanatta, D.T., Harris, A.T., 2013. Phylogeography and Genetic Variability of the Freshwater Mussels (Bivalvia: Unionidae) Ellipse, Venustaconcha ellipsiformis (Conrad 1836), and Bleeding Tooth, V. Pleasii (Marsh 1891). Am. Malacol. Bull. 31, 267-279. http://dx.doi.org/10.4003/006.031.0206.

Zogaris, S., Economou, A.N., Dimopoulos, P., 2009. Ecoregions in the Southern Balkans: should their boundaries be revised? Environ. Manage. 43, 682-697. http://dx.doi.org/10.1007/s00267-008-9243-y.

Zouros, E., Ball, A.O., Saavedra, C., Freeman, K.R., 1994a. Mitochondrial DNA inheritance. Nature 368, 818. http://dx.doi.org/10.1038/368818a0.

Zouros, E., Oberhauser Ball, A., Saavedra, C., Freeman, K.R., 1994b. An unusual type of mitochondrial DNA inheritance in the blue mussel Mytilus. Proc. Natl. Acad. Sci. 91, 7463-7467. http://dx.doi.org/10.1073/pnas.91.16.7463. 